\title{
Experimental Study on Performance Influencing Factors and Reasonable Mixture Ratio of Desert Sand Ceramsite Lightweight Aggregate Concrete
}

\author{
Songlin Zhang, Kang Yuan $\mathbb{D}$, Jiaming Zhang, and Junlin Guo \\ College of Hydraulic and Civil Engineering, Shihezi University, No. 221 Beisi Road, Shihezi, Xinjiang 832003, China \\ Correspondence should be addressed to Kang Yuan; williamyuan1982@163.com
}

Received 16 August 2019; Revised 12 December 2019; Accepted 23 January 2020; Published 17 February 2020

Academic Editor: Luigi Di Sarno

Copyright ( 2020 Songlin Zhang et al. This is an open access article distributed under the Creative Commons Attribution License, which permits unrestricted use, distribution, and reproduction in any medium, provided the original work is properly cited.

\begin{abstract}
The utilization of desert sand for making ceramsite lightweight aggregate concrete is proposed to make full use of local natural resources in the development of a new type of lightweight and load-bearing wall material with good energy conservation, waste utilization, and thermal insulation performances. An orthogonal test was conducted to analyze the effects of the water-binder ratio, sand ratio, desert sand substitution rate, and fly ash content on the slump, apparent density, and tube crushing strength of desert sand ceramsite lightweight aggregate concrete. Thus, the optimal mixture ratio of the desert sand ceramsite concrete was obtained for the LC20 and LC25 strength grades. Based on two reasonable mixture ratios, the physical and mechanical properties of the desert sand ceramsite concrete were investigated. The results revealed that the water-binder ratio, sand ratio, and desert sand substitution rate were the main influencing factors, and the influence law is essentially consistent with that of ordinary desert sand concrete. Based on the reasonable substitution rate of desert sand, the main physical and mechanical properties of the desert sand ceramsite lightweight aggregate concrete, such as the tube crushing strength, tensile strength, and thermal conductivity, satisfied the requirements of the Chinese code's specifications. In summary, desert sand can replace ordinary sand in ceramsite lightweight aggregate concrete for the production of new lightweight and load-bearing wall materials.
\end{abstract}

\section{Introduction}

Ceramsite lightweight aggregate concrete has an apparent density of less than $1950 \mathrm{~kg} / \mathrm{m}^{3}$ and uses ceramsite as a coarse aggregate. Nowadays, this concrete type has become the second most widespread type after ordinary concrete, owing to its advantages of low weight, high strength, and low thermal conductivity, amongst others [1-3]. The application of this concrete to new wall materials, such as lightweight wallboards and hollow blocks, can not only effectively reduce the weight and improve the seismic performance of buildings but also significantly improve the energy efficiency of the building [4-8]. Additionally, using local resources to develop new building materials is also an effective way to improve the energy efficiency of buildings. In desert areas, desert sand is a natural resource available in high quantities and low cost and its use in building materials is very important for the sustainable development of desert areas. From the above description, ceramsite lightweight aggregate concrete using desert sand instead of river sand not only is beneficial in improving the seismic performance and thermal insulation properties of buildings but also facilitates the rational use of rich sand resources in desert areas. Therefore, there is sufficient motivation for relevant research.

In recent years, some progress has been made in the study of desert sand as a fine aggregate of concrete. AlHarthy et al. [9] used desert sand with a fineness modulus between 0.45 and 0.88 to replace medium sand at a ratio of $10 \%$ to $100 \%$. The effects of desert sand on the workability, tube crushing strength, elastic modulus, and surface water absorption of concrete were analyzed. Luo et al. [10] compared the mechanical properties of desert sand concrete to those of ordinary concrete with the same water-cement ratio of 0.5 and demonstrated that the strength was slightly 
higher than that of ordinary concrete, owing to the desert sand's finer particle size. Additionally, it was demonstrated that the porosity between the cement slurry and aggregate could be filled. However, if the desert sand content is too high, a lot of water is absorbed on the surface and more bubbles are introduced during the stirring process, which reduces the concrete's strength. Seif et al. [11] investigated the mechanical and construction properties of concrete prepared using desert sand in the region of Arabia. The results revealed that the desert sand content should not exceed $50 \%$ of the total volume of fine aggregate. Rmili et al. [12], Bouziani et al. [13], Zhang et al. [14], Zhang et al. [15], Li et al. [16], Fu et al. [17], Jiang et al. [18], and Haifeng et al. [19] have also investigated the mechanical properties and influencing factors of desert sand concrete. From the abovementioned literature, it is understood that existing research on desert sand concrete has mainly focused on ordinary concrete, while the application of desert sand to ceramsite lightweight aggregate concrete has not been investigated yet.

Therefore, to obtain a reasonable mixture ratio of desert sand ceramsite lightweight aggregate concrete with good construction performance, mechanical properties, and thermal insulation performance, according to the needs of ordinary multistory buildings, this study designed four single factors, namely, the different waterbinder ratio, different volume sand ratio, different desert sand substitution rate, and different fly ash content. Moreover, orthogonal tests were conducted on 16 groups of 96 pieces of sand cube specimens of desert sand ceramsite concrete. A reasonable mixture ratio of LC20 and LC25 desert sand ceramsite lightweight aggregate concrete was obtained by analyzing the effects of various factors on slump, the natural apparent density after 28 days, and the tube crushing strength after seven days and 28 days. Hence, the axial tube crushing strength, static elastic modulus, splitting tensile strength, and thermal conductivity of the desert sand ceramsite lightweight aggregate concrete were tested. The obtained results can provide a theoretical basis and be useful as technical guidelines for the use of desert sand in ceramsite lightweight aggregate concrete.

\section{Test Materials and Methods}

2.1. Test Materials. The cement, water, and additives were used in the test: (1) cement: P.O. 42.5 grade ordinary Portland cement produced by Tianye cement Factory, Shihezi City, Xinjiang. (2) Fly ash: grade/fly ash (class F) produced by the Tianfu Energy Co. Ltd., in Xinjiang. (3) Water reducing agent: early strength water reducer produced by the Shihezi Changhong Concrete Admixture Factory, the water reducing rate was approximately $15 \%$, and the optimal content of the cementitious material was between $1.5 \%$ and $2 \%$. (4) Water: tap water was used for both maintenance and mixing water. The chemical properties of cement, fly ash, and water reducing agent are shown in Tables 1 and 2, and the physical properties are shown in Table 3.
The aggregate was used in the test: (1) lightweight aggregate: crushed shale ceramsite produced in Shawan, Xinjiang, with a good gradation design and particle size between 5 and $20 \mathrm{~mm}$. The relevant performance indices were determined according to the Chinese code titled "Light Aggregate and Its Test Method" (GB/T17431.2-2010) [20]; the results are presented in Table 4. (2) Desert sand: floating sand was taken from the Gultongbangut Desert in the Junggar Basin, Xinjiang. With an average particle size of $0.183 \mathrm{~mm}$ and a fineness modulus of 0.334 , the sand is categorized as superfine sand; the packing density was $1615 \mathrm{~kg} / \mathrm{m}^{3}$. The sand's chemical composition is presented in Table 5. (3) Ordinary sand: washed river sand (medium sand) with a diameter of less than $5 \mathrm{~mm}$ was used; the fineness modulus was 2.6 and the packing density was $1420 \mathrm{~kg} / \mathrm{m}^{3}$.

\subsection{Testing Scheme}

2.2.1. Orthogonal Tests Design. In the tests, the effects of the water-binder ratio, volume sand ratio, desert sand substitution rate, and fly ash content on the slump, apparent density, and tube crushing strength of the desert sand ceramsite concrete were considered. The objective of the tests was to obtain a reasonable mixture ratio for the desert sand ceramsite lightweight aggregate concrete with good workability, light bulk density, and sufficient strength to satisfy the requirements for the load-bearing walls of multistory buildings. To reduce the number of tests, the orthogonal tests scheme with five factors and four levels was adopted. The water-binder ratio, volume sand ratio, and fly ash content were determined according to the approximate scope of the Chinese code titled "Technical Regulations for Lightweight Aggregate Concrete (JGJ51-2002) [21]. Additionally, based on the results of existing studies, desert sand substitution rate did not exceed $50 \%$. The levels of each factor are presented in Table 6. The last table column is empty so that it can be used for error testing. In accordance with the Chinese code specifications [21], the mix proportion design of desert sand ceramsite lightweight aggregate concrete was carried out using the loose volume method. The total volume of the coarse and fine aggregate was $1.3 \mathrm{~m}^{3}$, the dosage of the water reducing agent was $2 \%$ of the cementitious materials, the dosage of each material is shown in Table 7, and all mixture ratios in the orthogonal tests were obtained by substituting each level of the factors as shown in Table 8.

\subsubsection{Testing Scheme for Physical and Mechanical Properties.} After applying the reasonable mixture ratio with good workability, light bulk density and sufficient strength were obtained from the orthogonal tests. The axial tube crushing strength, static elastic modulus, splitting tensile strength, and thermal conductivity tests of the desert sand ceramsite lightweight aggregate concrete were carried out with this mixture ratio. By comparing the corresponding indices of the ordinary lightweight aggregate concrete specified in the Chinese code [21], the application feasibility of desert sand 
TABle 1: The chemical properties of cement and fly ash.

\begin{tabular}{lccccccccc}
\hline Components (\%) & $\mathrm{SiO}_{2}$ & $\mathrm{Al}_{2} \mathrm{O}_{3}$ & $\mathrm{Fe}_{2} \mathrm{O}_{3}$ & $\mathrm{CaO}$ & $\mathrm{MgO}$ & $\mathrm{Na}_{2} \mathrm{O}$ & $\mathrm{Ka}_{2} \mathrm{O}$ & $\mathrm{SO}_{3}$ & Ignition loss \\
\hline Cement & 20.78 & 4.21 & 2.96 & 63.10 & 2.27 & 0.71 & 0.71 & 0.63 & 3.14 \\
Fly ash & 58.79 & 23.41 & 6.71 & 4.47 & 1.68 & 1.05 & 1.69 & 0.3 & 1.9 \\
\hline
\end{tabular}

TABLE 2: The main chemical properties of water reducing agent.

\begin{tabular}{lcccccc}
\hline Main components (\%) & Salt & Isopropanol & Acetone & Sodium citrate & Sodium hydroxide & Pigment \\
\hline Water reducing agent & 28.71 & 0.69 & 2.14 & 4.51 & 2.89 & 0.06 \\
\hline
\end{tabular}

TABle 3: The physical properties of cement and fly ash.

\begin{tabular}{|c|c|c|c|c|c|}
\hline Project components & Bulk density & Fineness & Proportion & Initial setting time & Final setting time \\
\hline Cement & $1300 \mathrm{~kg} / \mathrm{m}^{3}$ & $\leq 40 \mu \mathrm{m}$ & 3.1 & $\geq 45 \mathrm{~min}$ & $\leq 10 \mathrm{~h}$ \\
\hline Fly ash & $1.77 \sim 2.43 \mathrm{~g} / \mathrm{cm}^{3}$ & $\leq 12 \%$ & - & - & - \\
\hline
\end{tabular}

Table 4: Performance indices of shale ceramsite.

\begin{tabular}{lcccccc}
\hline $\begin{array}{l}\text { Technical } \\
\text { index }\end{array}$ & $\begin{array}{c}\text { Bulk density } \\
\left(\mathrm{kg} / \mathrm{m}^{3}\right)\end{array}$ & $\begin{array}{c}\text { Numerical tube pressure } \\
(\mathrm{MPa})\end{array}$ & $\begin{array}{c}\text { Water absorption } \\
(\%)\end{array}$ & $\begin{array}{c}\text { Softening } \\
\text { coefficient }\end{array}$ & $\begin{array}{c}\text { Silt content } \\
(\%)\end{array}$ & $\begin{array}{c}\text { Mass loss after boiling } \\
(\%)\end{array}$ \\
\hline Standard & - & $\geq 1.0$ & $\leq 10$ & $\geq 0.8$ & $\leq 3.0$ & $\leq 5.0$ \\
Actual value & 659 & 3.6 & 4.3 & 1 & 0.2 & 1 \\
\hline
\end{tabular}

TABLE 5: Chemical constituents of desert sand.

\begin{tabular}{cccccccccccc}
\hline $\mathrm{SiO}_{2}$ & $\mathrm{Al}_{2} \mathrm{O}_{3}$ & $\mathrm{Fe}_{2} \mathrm{O}_{3}$ & $\mathrm{FeO}$ & $\mathrm{TiO}_{2}$ & $\mathrm{P}_{2} \mathrm{O}_{5}$ & $\mathrm{MnO}$ & $\mathrm{CaO}$ & $\mathrm{MgO}$ & $\mathrm{K}_{2} \mathrm{O}$ & $\mathrm{Na}_{2} \mathrm{O}$ & $\mathrm{O}$ thers \\
\hline 64.58 & 9.48 & 2.32 & 0.85 & 0.24 & 0.06 & 0.05 & 8.62 & 2.06 & 1.97 & 2.43 & 7.34 \\
\hline
\end{tabular}

TABLE 6: Factor levels in orthogonal tests.

\begin{tabular}{lccccc}
\hline Level & Water-binder ratio $A$ & Sand ratio $B(\%)$ & Desert sand substitution rate $C(\%)$ & Fly ash content $D(\%)$ & Empty column $E$ \\
\hline 1 & 0.35 & 35 & 0 & 0 & 1 \\
2 & 0.4 & 38 & 20 & 15 & 2 \\
3 & 0.45 & 41 & 30 & 20 & 3 \\
4 & 0.5 & 45 & 40 & 25 & 4 \\
\hline
\end{tabular}

TABLE 7: The dosage of each material.

\begin{tabular}{|c|c|c|c|c|c|c|c|}
\hline \multirow{2}{*}{ Test mixture } & \multicolumn{7}{|c|}{ Amount of raw materials $\left(\mathrm{kg} / \mathrm{m}^{3}\right)$} \\
\hline & Cement & Water & River sand & Desert sand & Ceramsite & Fly ash & Water reducing agent \\
\hline 1 & 437.14 & 153.00 & 614.30 & 0.00 & 473.20 & 0.00 & 8.74 \\
\hline 2 & 371.57 & 153.00 & 533.50 & 159.60 & 451.40 & 65.57 & 8.74 \\
\hline 3 & 349.71 & 153.00 & 503.70 & 258.20 & 429.50 & 87.43 & 8.74 \\
\hline 4 & 327.86 & 153.00 & 473.90 & 377.90 & 400.40 & 109.29 & 8.74 \\
\hline 5 & 306.00 & 153.00 & 491.40 & 147.00 & 473.20 & 76.50 & 7.65 \\
\hline 6 & 286.87 & 153.00 & 666.90 & 0.00 & 451.40 & 95.63 & 7.65 \\
\hline 7 & 382.50 & 153.00 & 431.70 & 344.30 & 429.50 & 0.00 & 7.65 \\
\hline 8 & 325.12 & 153.00 & 552.80 & 283.40 & 400.40 & 57.38 & 7.65 \\
\hline 9 & 255.00 & 153.00 & 430.00 & 220.40 & 473.20 & 85.00 & 6.80 \\
\hline 10 & 272.00 & 153.00 & 400.10 & 319.10 & 451.40 & 68.00 & 6.80 \\
\hline 11 & 289.00 & 153.00 & 719.60 & 0.00 & 429.50 & 51.00 & 6.80 \\
\hline 12 & 340.00 & 153.00 & 631.80 & 189.00 & 400.40 & 0.00 & 6.80 \\
\hline 13 & 260.10 & 153.00 & 368.60 & 293.90 & 473.20 & 45.90 & 6.12 \\
\hline 14 & 306.00 & 153.00 & 466.80 & 239.30 & 451.40 & 0.00 & 6.12 \\
\hline 15 & 229.50 & 153.00 & 575.60 & 172.20 & 429.50 & 76.50 & 6.12 \\
\hline 16 & 244.80 & 153.00 & 789.80 & 0.00 & 400.40 & 61.20 & 6.12 \\
\hline
\end{tabular}


TABLE 8: Mixture ratio of orthogonal tests.

\begin{tabular}{lccccc}
\hline \multirow{2}{*}{ Test mixture } & \multicolumn{5}{c}{ Factor } \\
& $A$ & $B$ & $C$ & $D$ & $E$ \\
\hline 1 & $1(0.35)$ & $1(35)$ & $1(0)$ & $1(0)$ & 1 \\
2 & 1 & $2(38)$ & $2(20)$ & $2(15)$ & 2 \\
3 & 1 & $3(41)$ & $3(30)$ & $3(20)$ & 3 \\
4 & 1 & $4(45)$ & $4(40)$ & $4(25)$ & 4 \\
5 & $2(0.40)$ & 1 & 2 & 3 & 4 \\
6 & 2 & 2 & 1 & 4 & 3 \\
7 & 2 & 3 & 4 & 1 & 2 \\
8 & 2 & 4 & 3 & 2 & 1 \\
9 & $3(0.45)$ & 1 & 3 & 4 & 2 \\
10 & 3 & 2 & 4 & 3 & 1 \\
11 & 3 & 3 & 1 & 2 & 4 \\
12 & 3 & 4 & 2 & 1 & 3 \\
13 & $4(0.50)$ & 1 & 4 & 2 & 3 \\
14 & 4 & 2 & 3 & 1 & 4 \\
15 & 4 & 3 & 2 & 4 & 1 \\
16 & 4 & 4 & 1 & 3 & 2 \\
\hline
\end{tabular}

in ceramsite lightweight aggregate concrete could be determined.

2.3. Test Methods. First, orthogonal tests were carried out to obtain reasonable mixture ratio for the desert sand ceramsite lightweight aggregate concrete by analyzing the slump, natural apparent density, and tube crushing strength. Subsequently, physical and mechanical property tests were carried out. Concrete mixing method: the ceramsite was prewet for one hour before stirring the concrete in each test so as to minimize the porosity and prevent the floating of the lightweight aggregate. The ceramsite and fine aggregate were poured into the mixer for 45 seconds; then, the cement was poured into the mixer for 45 seconds to make the distribution of the aggregate more uniform. Finally, water containing a water reducing agent was added to the mix for two minutes.

The slump, apparent density, physical and mechanical property, and thermal conductivity are tested one by one. (1) Slump test: the test was carried out in accordance with the Chinese code titled "Standard for Performance Test Method of Ordinary Concrete Mixture” (GB/T 50080-2016) [22]. (2) Apparent density test: obtained by dividing the mass of the specimen by its volume in the natural state. (3) Physical and mechanical property tests: the tube crushing strength and splitting tensile strength specimens were $100 \mathrm{~mm} \times 100 \mathrm{~mm} \times 100 \mathrm{~mm}$ cubes; the axial tube crushing strength and static elastic modulus specimens were $150 \mathrm{~mm} \times 150 \mathrm{~mm} \times 300 \mathrm{~mm}$ prisms. The tests were carried out in accordance with the Chinese code titled "Standard for Test Methods of Mechanical Properties of Ordinary Concrete"(GB/T 50081-2002) [23]. (4) Thermal conductivity test: each specimen was put into the JTRG-111 thermal conductivity tester; the temperature of the cold plate was set to $10^{\circ} \mathrm{C}$, while that of the hot plate was set to $30^{\circ} \mathrm{C}$. The thermal conductivity was calculated automatically using thermal conductivity measurement software directly through the heat transfer in the cold-hot plate.

\section{Test Results and Discussion}

3.1. Orthogonal Tests Results and Analysis. The slump, natural apparent density, and cubic tube crushing strength of the fresh concrete were obtained from the orthogonal tests. The results are presented in Table 9.

3.1.1. Range Analysis. The factors degree of influence can be determined by range analysis. The range analysis performed on the orthogonal test results is presented in Table 10.

From Table 10, the following can be seen: (1) for the slump of fresh desert sand ceramsite concrete, the order of the influence factors is as follows: $A$ (water-binder ratio) $>C$ (desert sand substitution rate) $>B$ ( sand ratio) $>D$ (fly ash content); (2) for the natural apparent density of the desert sand ceramsite concrete, the order of influence factors is as follows: $B>A>C>D$; (3) for the tube crushing strength of the desert sand ceramsite concrete, the order of influence factors is as follows: $A>B>C>D$.

3.1.2. Variance Analysis. Range analysis is simple, intuitive, and computational but cannot distinguish whether the difference in the results is caused by the level change of each factor or by random fluctuations in the test. The F test can solve this problem by employing variance analysis. The results are presented in Table 11 .

The $F$ test results revealed that the water-binder ratio, sand ratio, and desert sand substitution rate exerted significant effects on the working performance of the desert sand ceramsite concrete. Moreover, the effect of the fly ash content was not obvious. Therefore, when determining the benchmark mixture ratio, the fly ash content could be considered as $15 \%$ for the LC20 strength grade and as $20 \%$ for the LC25 strength grade of light aggregate concrete, according to the literature [21].

3.1.3. Factor Index Analysis. Through range analysis and variance analysis, it was found that the water-binder ratio, sand ratio, and desert sand substitution rate are the main factors affecting the performance of desert sand ceramsite concrete. However, owing to the large error in the blank column and the small degree of error freedom (only 3 ), the testing sensitivity was low. Accordingly, when determining the base mixture ratio, the three factors should be comprehensively analyzed and their appropriate level should be selected according to the actual needs.

(1) Effect of Water-Binder Ratio on Performances of Desert Sand Ceramsite Lightweight Aggregate Concrete. Figure 1 shows the relationship between the water-binder ratio and the properties of the desert sand ceramsite concrete. As can be seen, the relationship between the water-binder ratio and the performance of the desert sand ceramsite concrete was essentially the same as that of ordinary concrete. The slump gradually increased with the increase of the waterbinder ratio, while the apparent density and tube crushing strength gradually decreased. To ensure a lightweight 
TABLE 9: Test results for mixture ratio.

\begin{tabular}{|c|c|c|c|c|c|c|c|c|c|}
\hline \multirow[t]{2}{*}{ Test mixture } & \multirow[t]{2}{*}{ Slump (mm) } & \multirow[t]{2}{*}{ Apparent density $\left(\mathrm{kg} / \mathrm{m}^{3}\right)$} & \multicolumn{2}{|c|}{$\begin{array}{c}\text { Tube } \\
\text { crushing } \\
\text { strength } \\
(\mathrm{MPa})\end{array}$} & \multirow[t]{2}{*}{ Test mixture } & \multirow[t]{2}{*}{ Slump (mm) } & \multirow[t]{2}{*}{ Apparent density $\left(\mathrm{kg} / \mathrm{m}^{3}\right)$} & \multicolumn{2}{|c|}{$\begin{array}{c}\text { Tube } \\
\text { crushing } \\
\text { strength } \\
(\mathrm{MPa})\end{array}$} \\
\hline & & & $7 \mathrm{~d}$ & $28 \mathrm{~d}$ & & & & $7 \mathrm{~d}$ & $28 \mathrm{~d}$ \\
\hline 1 & 49 & 1707.9 & 19.6 & 27.2 & 9 & 66 & 1681.4 & 15.1 & 24.1 \\
\hline 2 & 44 & 1750.8 & 21.1 & 31.5 & 10 & 76 & 1725.3 & 17.2 & 27.6 \\
\hline 3 & 56 & 1800.2 & 24.6 & 34.4 & 11 & 98 & 1735.8 & 19.1 & 27.3 \\
\hline 4 & 52 & 1832.5 & 25.4 & 35.7 & 12 & 60 & 1780.3 & 21.1 & 29.4 \\
\hline 5 & 48 & 1730.1 & 19.2 & 26.6 & 13 & 82 & 1698.8 & 16.2 & 23.6 \\
\hline 6 & 84 & 1720.2 & 19.4 & 27.5 & 14 & 85 & 1710.3 & 18.5 & 26.6 \\
\hline 7 & 54 & 1794.9 & 22.5 & 32.2 & 15 & 66 & 1691 & 14.3 & 23.2 \\
\hline 8 & 52 & 1800.6 & 20.3 & 30.1 & 16 & 84 & 1720.8 & 14.9 & 22.6 \\
\hline
\end{tabular}

TABLE 10: Range analysis.

\begin{tabular}{|c|c|c|c|c|c|c|}
\hline \multirow{2}{*}{ Index of test } & \multirow{2}{*}{ Range } & \multicolumn{4}{|c|}{ Factor } & \multirow{2}{*}{ Disturbance term } \\
\hline & & $A$ & $B$ & C & $D$ & \\
\hline Slump & $\mathrm{R}_{1}$ & 29.00 & 11.00 & 24.25 & 7.00 & 10.00 \\
\hline Apparent density & $\mathrm{R}_{2}$ & 67.63 & 79.00 & 41.70 & 17.08 & 20.98 \\
\hline 7 days' tube crushing strength & $\mathrm{R}_{3}$ & 6.70 & 2.90 & 2.08 & 1.88 & 2.70 \\
\hline 28 days' tube crushing strength & $\mathrm{R} 4$ & 8.20 & 4.08 & 3.63 & 1.23 & 2.03 \\
\hline
\end{tabular}

TABLe 11: $F$ test results.

\begin{tabular}{|c|c|c|c|c|c|c|}
\hline \multirow{2}{*}{ Index of test } & \multirow{2}{*}{$F$} & \multicolumn{4}{|c|}{ Factor } & \multirow{2}{*}{ Critical value } \\
\hline & & $A$ & $B$ & C & $D$ & \\
\hline Slump & $F_{1}$ & $32.662^{* * *}$ & $5.94^{*}$ & $9.862^{* *}$ & 0.602 & $\mathrm{~F}_{0.01}(3,3)=29.5$ \\
\hline Apparent density & $F_{2}$ & $9.173^{*}$ & $11.577^{* *}$ & $6.018^{*}$ & 0.584 & $\mathrm{~F}_{0.05}(3,3)=9.28$ \\
\hline 7 days' tube crushing strength & $F_{3}$ & $9.596^{* *}$ & $7.626^{*}$ & $5.41^{*}$ & 0.353 & $\mathrm{~F}_{0.1}(3,3)=5.39$ \\
\hline 28 days' tube crushing strength & $F_{4}$ & $13.416^{* *}$ & $6.832^{*}$ & $5.694^{*}$ & 0.447 & \\
\hline
\end{tabular}

Note. When $F>F_{0.01}$, the influence of factors is significant, and the factor is marked as ${ }^{* * *}$; when $F>F_{0.05}$, the factor is marked as ${ }^{* *}$; when $F>F_{0.1}$, the factor is marked as *.

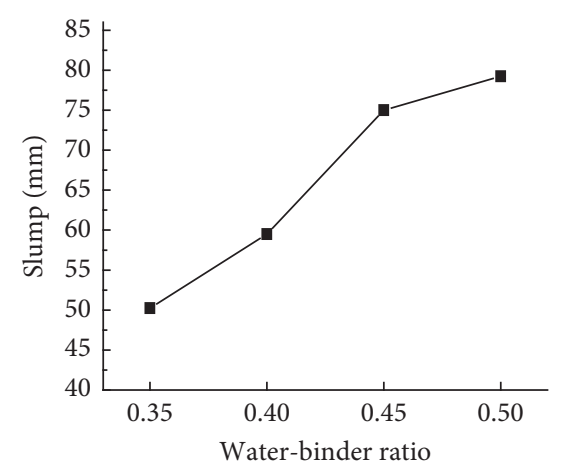

(a)

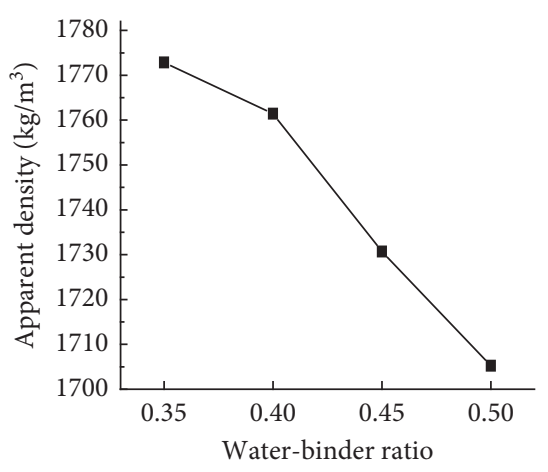

(b)

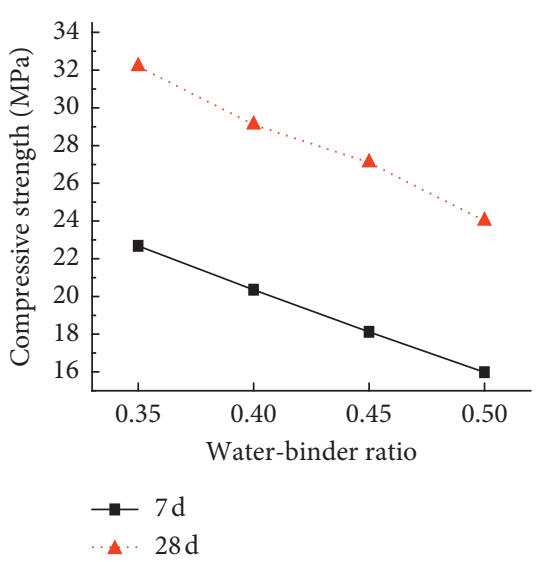

(c)

Figure 1: Curves of relationship between water-binder ratio and performance of desert sand ceramsite concrete. (a) Trend curve of slump. (b) Trend curve of 28 days' natural apparent density. (c) Trend curve of 7 and 28 days' tube crushing strength.

material, the optimal water-binder ratio of the desert sand ceramsite concrete with the LC20 and LC25 strength grades was approximately 0.5 and 0.45 , respectively. At this time, the concrete slump was the largest, the apparent density was the smallest, and the strength satisfied the requirements. 
(2) Effect of Sand Ratio on Performances of Desert Sand Ceramsite Lightweight Aggregate Concrete. Figure 2 shows the relationship between the sand ratio and the performance of the desert sand ceramsite concrete. The following observations can be made: (1) the slump of the desert sand ceramsite concrete first increased and then decreased as the sand ratio increased, and then reached the maximum value when the volume sand ratio was $38 \%$; (2) the apparent density increased in an approximately linear manner with the increase of the volume sand ratio; (3) the tube crushing strength increased faster when the volume sand ratio increased from $35 \%$ to $41 \%$; subsequently, the increase slowed down.

The obtained results revealed that the effects of sand ratio on the performance of desert sand ceramsite lightweight aggregate concrete were similar to those for ordinary ceramsite lightweight aggregate concrete, as mentioned in the literature [5]. The strength of lightweight aggregate concrete was improved by increasing the sand ratio within a certain range. However, when the sand ratio was too high, the content of the cement slurry relatively decreased, and the coarse aggregate could not be fully wrapped. This resulted in an uneven internal structure for the concrete and the strength stopped increasing or decreasing with the increase of the sand ratio. Moreover, as the sand ratio increased, the apparent density of the concrete also increased. Therefore, it is necessary to choose a volume sand ratio that can achieve high strength and low density, so as to ensure that the concrete has adequate workability for easy construction. Overall, the sand ratio of the desert sand ceramsite lightweight aggregate concrete with the LC20 and LC25 strength grades should be controlled at approximately $38 \%-41 \%$.

\section{(3) Effect of Desert Sand Substitution Rate on Performances of} Desert Sand Ceramsite Lightweight Aggregate Concrete. Figure 3 shows the relationship between the substitution rate of the desert sand and the performance of the desert sand ceramsite concrete. The following observations can be made: (1) first, the slump of the desert sand ceramsite lightweight aggregate concrete decreased approximately with the increase of the desert sand substitution rate. When desert sand was not mixed, the slump reached its maximum value. When the desert sand substitution rate increased from 0 to $20 \%$, the slump of the desert sand ceramsite concrete sharply decreased. However, when the desert sand substitution rate increased from $20 \%$ to $30 \%$, the slump of the desert sand ceramsite concrete increased again. This occurred because the desert sand had a smaller particle size and larger specific surface area; thus, it filled the internal voids of the slurry, which resulted in the increase of the concrete's viscosity and the decrease of slump. Because the surface of the desert sand was smooth, the friction between the aggregates decreased and the slump increased as the desert sand content increased. However, the increase slowed down after exceeding a certain amount. (2) Because the desert sand filled the internal voids of the concrete, the apparent density and tube crushing strength slightly increased as the desert sand substitution rate increased.
The test results revealed that the effects of the desert sand on the performance of lightweight aggregate concrete are similar to those of the desert sand ordinary concrete reported in the literature $[10,11,15]$. Specifically, when the desert sand substitution rate was below $40 \%$, the workability of the lightweight aggregate concrete decreased, while the apparent density and tube crushing strength slightly increased. To satisfy the reasonable slump requirement, the desert sand substitution rate should be more than $30 \%$. Considering both the strength and workability requirements, for the LC20 strength grade of the desert sand ceramsite concrete, the desert sand substitution rate should be 30\%, whereas for the LC25 strength grade, the desert sand substitution rate should be $40 \%$.

\subsubsection{Determination of Benchmark Mixture Ratio.} According to the above analysis, the final factor levels determined by the orthogonal tests are as follows: for the LC20 strength grade, the water-binder ratio was 0.5 , the sand ratio was $38 \%$, the desert sand substitution rate was $30 \%$, and the fly ash content was $15 \%$. For the LC25 strength grade, the water-binder ratio was 0.45 , the sand ratio was $41 \%$, the desert sand substitution rate was $40 \%$, and the fly ash content was $20 \%$.

The total volume $V$ was $1.3 \mathrm{~m}^{3}$, and the reference mixture ratio calculated by the loose volume method is presented in Table 12 .

The 16 groups of mixture ratios in the orthogonal tests do not include the final mixture ratios of the LC20 and LC25 desert sand ceramsite concrete (Table 9). Therefore, it was necessary to repeat the experiments for the two mixture ratios to verify their accuracy. The methods and test subjects were the same as those in the previous orthogonal tests. The average values of the test results are listed in Table 13.

From Table 13, it can be seen that the two groups of the desert sand ceramsite concrete, which were made from the benchmark mixture ratio, had better fluidity, their apparent density was lower than $1950 \mathrm{~kg} / \mathrm{m}^{3}$, which is the Chinese code's specification for lightweight aggregate concrete [21], and the tube crushing strength could satisfy the requirements. The test results revealed that the benchmark mixture ratios of the two strength grades were adequately reasonable.

\subsection{Test Results and Analysis of Physical and Mechanical} Properties. The test results for the physical and mechanical properties of the desert sand ceramsite concrete with the LC20 and LC25 strength grades and related indices of ordinary lightweight aggregate concrete specified in the literature [21] are listed in Table 14.

From Table 14, the following can be seen: (1) the main physical and mechanical properties of the desert sand ceramsite lightweight aggregate concrete with the two mixture ratios determined by the orthogonal tests essentially satisfied the requirements for ordinary lightweight aggregate concrete with the same strength grade [21]. (2) The axial tube crushing strength of the desert sand ceramsite lightweight aggregate concrete was slightly lower than its cubic tube crushing strength, and its ratio was approximately 0.93 . (3) 


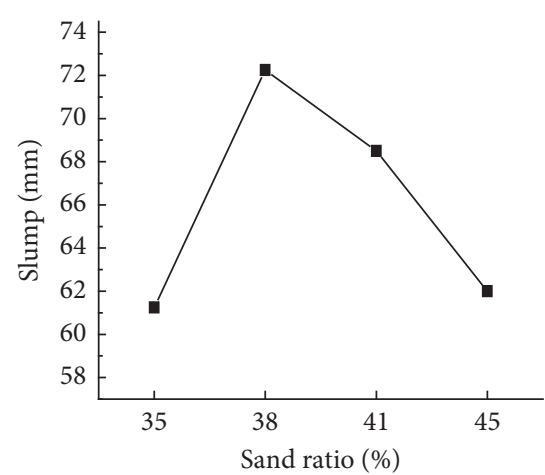

(a)

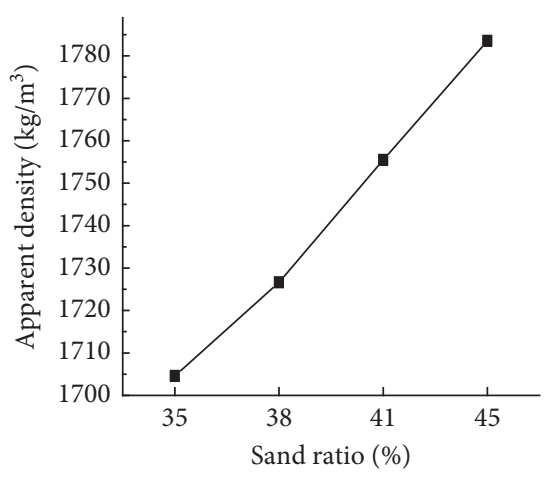

(b)

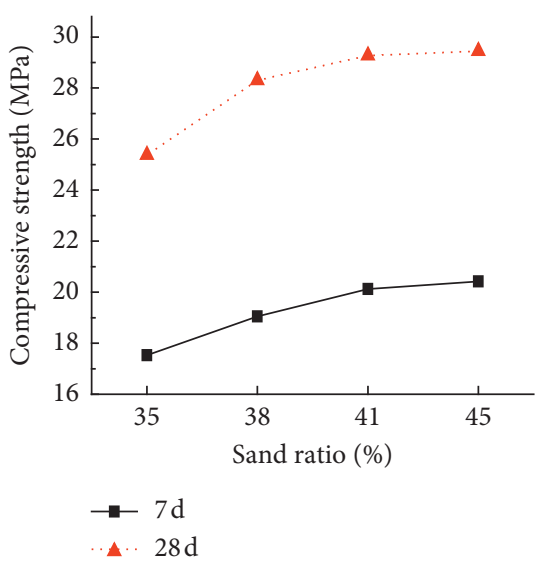

(c)

Figure 2: Curves of relationship between sand ratio and performance of desert sand ceramsite concrete. (a) Trend curve of slump. (b) Trend curve of 28 days' natural apparent density. (c) Trend curve of 7 and 28 days' tube crushing strength.

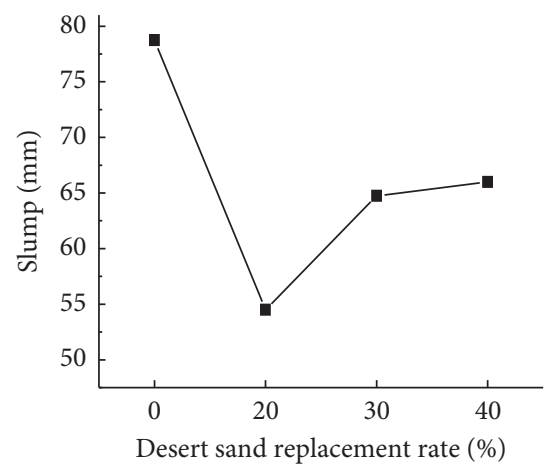

(a)

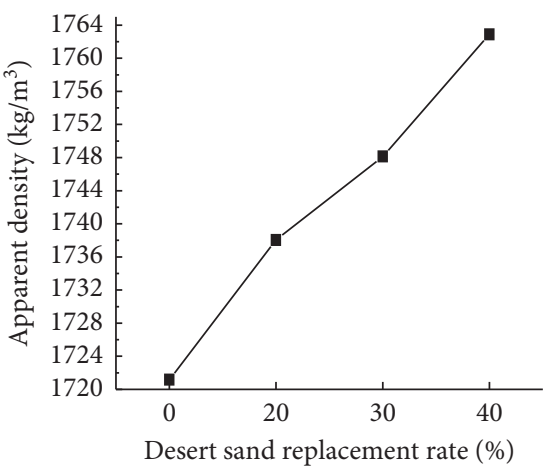

(b)

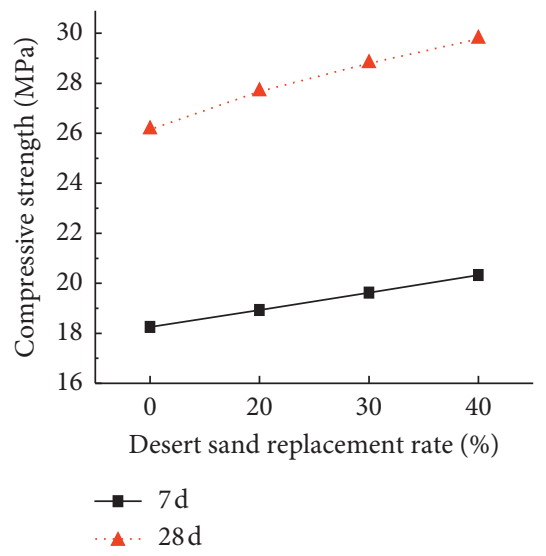

(c)

Figure 3: Curves of relationship between desert sand substitution rate and performance of desert sand ceramsite concrete. (a) Trend curve of slump. (b) Trend curve of 28 days' natural apparent density. (c) Trend curve of 7 and 28 days' tube crushing strength.

TABLE 12: Benchmark mixture ratio of desert sand ceramsite lightweight aggregate concrete.

\begin{tabular}{lcccccrr}
\hline Strength grade & Cement & Fly ash & Ceramsite & River sand & Desert sand & Water reducing agent & Water \\
\hline LC20 & 260.1 & 45.9 & 451.4 & 466.8 & 239.3 & 6.1 & 153.0 \\
LC25 & 272.0 & 68.0 & 400.4 & 552.8 & 283.4 & 6.8 & 153.0 \\
\hline
\end{tabular}

TABLE 13: Test results of benchmark mixture ratio.

\begin{tabular}{|c|c|c|c|c|}
\hline \multirow[t]{2}{*}{ Strength grade } & \multirow[t]{2}{*}{ Slump (mm) } & \multirow[t]{2}{*}{ Apparent density $\left(\mathrm{kg} / \mathrm{m}^{3}\right)$} & \multicolumn{2}{|c|}{$\begin{array}{l}\text { Tube crushing strength } \\
(\mathrm{MPa})\end{array}$} \\
\hline & & & $7 \mathrm{~d}$ & $28 \mathrm{~d}$ \\
\hline LC20 & 86 & 1707.9 & 15.9 & 24.0 \\
\hline LC25 & 74 & 1734.6 & 19.0 & 28.5 \\
\hline
\end{tabular}

The elastic modulus of the desert sand ceramsite lightweight aggregate concrete was approximately $25 \%$ higher than that of ordinary lightweight aggregate concrete with the same grade because the desert sand had finer particle size and filled the internal voids of the concrete. Under the same action force, the deformation of the desert sand lightweight aggregate concrete will be smaller than that of ordinary lightweight aggregate concrete, and the corresponding elastic modulus will increase. (4) The thermal conductivity of the two strength grades of the desert sand ceramsite concrete 
TABLE 14: Main physical and mechanical properties of desert sand ceramsite lightweight aggregate concrete.

\begin{tabular}{lccccc}
\hline Strength grade & $\begin{array}{c}\text { Cubic tube crushing } \\
\text { strength }(\mathrm{MPa})\end{array}$ & $\begin{array}{c}\text { Axial tube crushing } \\
\text { strength }(\mathrm{MPa})\end{array}$ & $\begin{array}{c}\text { Static elastic modulus } \\
\left(\times 10^{3} \mathrm{MPa}\right)\end{array}$ & $\begin{array}{c}\text { Splitting tensile } \\
\text { strength }(\mathrm{MPa})\end{array}$ & $\begin{array}{c}\text { Thermal conductivity } \\
(\mathrm{W} /(\mathrm{m} \mathrm{K}))\end{array}$ \\
\hline LC20 & 24.0 & 22.3 & 18.23 & 1.95 & 0.3378 \\
GJ51-2002[21] & 20.0 & 13.4 & $14.5-15.4$ & 1.54 & 0.66 \\
LC25 & 28.5 & 26.7 & 21.66 & 2.21 & 0.3616 \\
GJ51-2002 [21] & 25.0 & 16.7 & $16.2-17.2$ & 1.78 & 0.76 \\
\hline
\end{tabular}

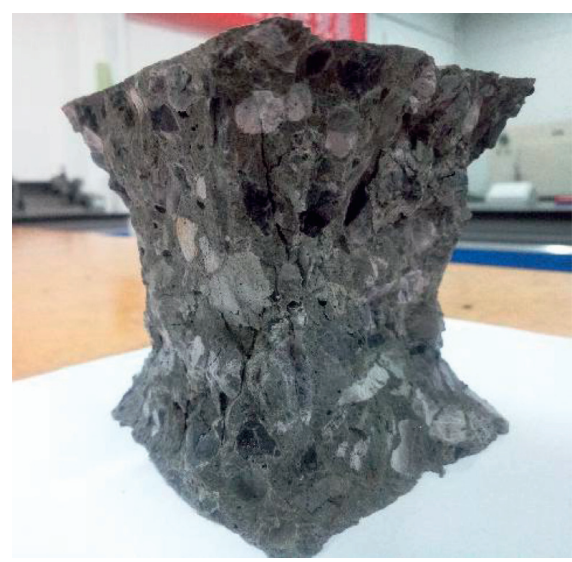

(a)

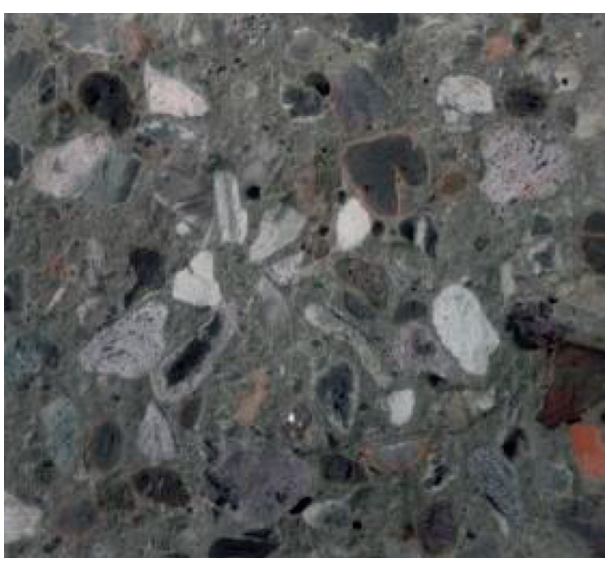

(b)

FIgURE 4: Test results for desert sand lightweight aggregate concrete. (a) Compressive failure mode. (b) Failure interface.

was lower than that reported in the literature [21]. This shows that the thermal insulation performance of ceramsite concrete mixed with desert sand can satisfy the requirements of the Chinese code, which further indicates that desert sand ceramsite concrete can be used to produce new lightweight walls with integrated heat preservation and load-bearing.

Figure 4 shows the failure mode and interface of the desert sand lightweight aggregate concrete under compression. Unlike the failure mode of ordinary concrete, whose failure surface develops at the cement stone-aggregate interface, the failure surface of the desert sand lightweight aggregate concrete not only did develop at the interface area but also passed through the lightweight aggregate, owing to its low strength.

\section{Conclusions}

In this study, orthogonal tests were conducted to investigate the effects of the water-binder ratio, sand ratio, desert sand substitution rate, and fly ash content on the slump, apparent density, and tube crushing strength of desert sand ceramsite lightweight aggregate concrete. Hence, a reasonable mixture ratio was obtained for the LC20 and LC25 strength grades. On this basis, the physical and mechanical properties of the desert sand ceramsite lightweight aggregate concrete were investigated. The main conclusions drawn from this study are as follows:

(1) The water-binder ratio, sand ratio, and desert sand substitution rate were the main factors affecting the performance of the desert sand ceramsite lightweight aggregate concrete, and the influence law is essentially consistent with that of ordinary concrete. (i) As the water-binder ratio increased, the slump gradually increased, and the apparent density and tube crushing strength gradually decreased. (ii) As the sand ratio increased, the slump first increased and then decreased and reached its peak value when the sand ratio was 38\%; the apparent density linearly increased and the tube crushing strength slightly increased. (iii) With the increase of the desert sand substitution rate, the slump first decreased and then increased and reached its minimum value when the desert sand substitution rate was 20\%. Moreover, the apparent density and tube crushing strength gradually increased.

(2) A reasonable mixture ratio was obtained for the two strength grades of the lightweight aggregate ceramsite concrete. The mixture ratio of the LC20 strength grade is as follows: water-binder ratio of 0.5 , sand ratio of $38 \%$, desert sand substitution rate of $30 \%$, and fly ash content of $15 \%$. The mixture ratio of the LC25 strength grade is as follows: water-binder ratio of 0.45 , sand ratio of $41 \%$, desert sand substitution rate of $40 \%$, and fly ash content of $20 \%$.

(3) It is technically feasible to use desert sand to replace ordinary sand in the production of ceramsite lightweight aggregate concrete. Based on the reasonable desert sand substitution rate, the technical indices, such as the bulk density, thermal conductivity, and slump, and the mechanical properties of the desert sand lightweight aggregate concrete can satisfy the required specifications. Desert sand 
lightweight aggregate concrete can be used in the large-scale production of new lightweight walls with integrated heat preservation and load-bearing, which has broad application prospects for multistory buildings in cold desert areas.

\section{Data Availability}

The experimental and numerical simulation data used to support the findings of this study have been deposited in the 4TU Centre for Research Data repository (DOI:10.4121/uuid: 6fb4f0e2-1433-4287-91e0-0495072bf3b7).

\section{Conflicts of Interest}

The authors declare no conflicts of interest.

\section{Acknowledgments}

This work was financially supported by the National Natural Science Foundation of China (Grant no. 51968062), the Major Science and Technology Project of Crops (Grant no. 2016AA02), and the High-level Talents Scientific Research Initiation Fund Project of Shihezi University (Grant no. RCZK2018C24). The authors gratefully acknowledge this support and relevant technical support.

\section{References}

[1] M.-H. Zhang and O. E. Gjorv, "Mechanical properties of highstrength lightweight concrete," ACI Materials Journal, vol. 88, no. 3, pp. 240-247, 1991.

[2] F. Curcio, D. Galeota, A. Gallo et al., "High-performance lightweight concrete for the precast prestressed concrete industry," Recent Advances in Concrete Technology, vol. 20, no. 2, pp. 131-140, 1998.

[3] Q. Yang and M. Shuan, "Present situation and development of lightweight Aggregate concrete," Railway Engineering, vol. 6, pp. 104-106, 2006.

[4] L. Li, Performance Tests and Analysis on Energy Saving Effect of Structural Concrete of Havdite Lightweight Aggregate, pp. 58-67, Zhejiang University, Hangzhou, China, 2015.

[5] L. Li and X. Qian, "Effect of sand ratio on the performance of creamsite lightweight Aggregate structural concrete," Journal of Materials Science and Engineering, vol. 33, no. 1, pp. 56-61, 2015.

[6] X. Huang, Z. Bian, and S. Huang, "Preparation and properties of lightweight creamsite concrete in prefabricated panel," Concrete, vol. 12, pp. 123-125, 2016.

[7] J. Liu, M. Ba, Z. He, and Y. Li, "Microstructure and performance of sludge-ceramisite concrete," Construction and Building Materials, vol. 39, no. 2, pp. 82-88, 2013.

[8] Z. Z. Jiao, Y. Wang, W. Z. Zheng et al., "Use of industrial waste slag in alkali-activated slag ceramsite concrete hollow blocks," Applied Sciences-Basel, vol. 8, no. 12, 2018.

[9] A. S. Al-Harthy, M. A. Halim, R. Taha, and K. S. Al-Jabri, "The properties of concrete made with fine dune sand," Construction and Building Materials, vol. 21, no. 8, pp. 1803-1808, 2007.

[10] F. J. Luo, L. He, Z. Pan, W. H. Duan, X. L. Zhao, and F. Collins, "Effect of very fine particles on workability and strength of concrete made with dune sand," Construction and Building Materials, vol. 47, no. 5, pp. 131-137, 2013.
[11] E. S. S. A. Seif, A. R. Sonbul, B. A. H. Hakami et al., "Experimental study on the utilization of dune sands as a construction material in the area between Jeddah and Mecca, Western Saudi Arabia," Bulletin of Engineering Geology and the Environment, vol. 75, no. 3, pp. 1007-1022, 2016.

[12] A. Rmili, M. B. Ouezdou, M. Added, and E. Ghorbel, "Incorporation of crushed sands and Tunisian desert sands in the composition of self compacting concretes Part II: SCC fresh and hardened states characteristics," International Journal of Concrete Structures and Materials, vol. 3, no. 1, pp. 11-14, 2009.

[13] T. Bouziani, M. Bederina, and M. Hadjoudja, "Effect of dune sand on the properties of flowing sand-concrete (FSC)," International Journal of Concrete Structures and Materials, vol. 6, no. 1, pp. 59-64, 2012.

[14] G. Zhang, J. Song, J. Yang, and X. Liu, "Performance of mortar and concrete made with a fine aggregate of desert sand," Building and Environment, vol. 41, no. 11, pp. 1478-1481, 2006.

[15] C. Zhang, W. Zhou, X. Ding et al., "Study on the application of desert superfine sand to the preparation of concrete," New Building Materials, no. 9, pp. 28-29, 2001.

[16] Z. Li, M. He, K. Yuan et al., "Desert sand concrete," CN105036651A, 2015.

[17] J. Fu, J. Ma, and H. Liu, "Influence of fly ash dosage and desert sand replacement ratio on the mechanical properties of desert sand concrete," Journal of Guangxi University, vol. 40, no. 1, pp. 93-98, 2015.

[18] C. Jiang, X. Zhou, G. Tao, and D. Chen, "Experimental study on the performance and microstructure of cementitious materials made with dune sand," Advances in Materials Science and Engineering, vol. 2016, Article ID 2158706, 8 pages, 2016.

[19] L. Haifeng, W. M. Jurong, and N. Jianguo, "Influence of desert sand on the mechanical properties of concrete subjected to impact loading," Acta Mechanica Solida Sinica, vol. 30, no. 6, pp. 583-595, 2017.

[20] China Construction Industry Press, GB/T 17431.2-2010, Lightweight Aggregates and Test Methods Part 2:Test Methods for Lightweight Aggregates, China Construction Industry Press, Beijing, China, 2010.

[21] China Construction Industry Press, JGJ 51-2002, Technical Specification for Lightweight Aggregate Concrete, China Construction Industry Press, Beijing, China, 2002.

[22] China Construction Industry Press, GB/T 50080-2016, Standard for Test Method of Performance of Ordinary Concrete Mixture, China Construction Industry Press, Beijing, China, 2016.

[23] China Construction Industry Press, GB/T 50081-2002, Standard for Test Method of Mechanical Properties of Ordinary Concrete, China Construction Industry Press, Beijing, China, 2002. 